\title{
Kunitz Proteinase Inhibitors Limit Water Stress Responses in White Clover (Trifolium repens L.) Plants
}

\author{
Afsana Islam ${ }^{\dagger}$, Susanna Leung, Aluh Nikmatullaht, Paul P. Dijkwel* and \\ Michael T. McManus ${ }^{\ddagger}$
}

Institute of Fundamental Sciences, Massey University, Palmerston North, New Zealand

\section{OPEN ACCESS}

Edited by:

Andy Pereira,

University of Arkansas, United States

Reviewed by:

Karl Kunert,

University of Pretoria, South Africa

Rainer Hofmann,

Lincoln University, New Zealand

*Correspondence:

Paul P. Dijkwel

p.dijkwel@massey.ac.nz

${ }^{\dagger}$ Present address:

Afsana Islam,

Department of Biological Sciences,

Thompson Rivers University,

Kamloops, BC, Canada

Aluh Nikmatullah,

University of Mataram, Mataram,

Indonesia

${ }^{\ddagger}$ Deceased

Specialty section:

This article was submitted to

Plant Abiotic Stress,

a section of the journal

Frontiers in Plant Science

Received: 23 May 2017 Accepted: 13 September 2017

Published: 04 October 2017

Citation:

Islam A, Leung S, Nikmatullah A,

Dijkwel PP and McManus MT (2017)

Kunitz Proteinase Inhibitors Limit Water Stress Responses in White

Clover (Trifolium repens L.) Plants.

Front. Plant Sci. 8:1683.

doi: $10.3389 / f p / s .2017 .01683$
The response of plants to water deficiency or drought is a complex process, the perception of which is triggered at the molecular level before any visible morphological responses are detected. It was found that different groups of plant proteinase inhibitors (Pls) are induced and play an active role during abiotic stress conditions such as drought. Our previous work with the white clover (Trifolium repens L.) Kunitz Proteinase Inhibitor $(T r-K P l)$ gene family showed that $T r-K P / s$ are differentially regulated to ontogenetic and biotic stress associated cues and that, at least some members of this gene family may be required to maintain cellular homeostasis. Altered cellular homeostasis may also affect abiotic stress responses and therefore, we aimed to understand if distinct $\operatorname{Tr}-P K I$ members function during drought stress. First, the expression level of three $T r-K P I$ genes, $T r-K P 11, T r-K P I 2$, and Tr-KPI5, was measured in two cultivars and one white clover ecotype with differing capacity to tolerate drought. The expression of $T r-K P 11$ and Tr-KPI5 increased in response to water deficiency and this was exaggerated when the plants were treated with a previous period of water deficiency. In contrast, proline accumulation and increased expression of Tr-NCED1, a gene encoding a protein involved in ABA biosynthesis, was delayed in plants that experienced a previous drought period. RNAi knock-down of Tr-KPI1 and Tr-KPI5 resulted in increased proline accumulation in leaf tissue of plants grown under both well-watered and water-deficit conditions. In addition, increased expression of genes involved in ethylene biosynthesis was found. The data suggests that Tr-KP/s, particularly Tr-KP/5, have an explicit function during water limitation. The results also imply that the Tr-KPI family has different in planta proteinase targets and that the functions of this protein family are not solely restricted to one of storage proteins or in response to biotic stress.

Keywords: water deficiency, Kunitz Proteinase Inhibitor, Trifolium repens, white clover, proline accumulation

\section{INTRODUCTION}

Plant Kunitz proteinase inhibitors (KPIs) belong to the serine proteinase inhibitor (PI) group and numerous KPIs have now been identified from different plant species (Rawlings et al., 2016). In most plant species, the KPIs comprise a multi-gene family: there are 13 members in soybean (Jofuku and Goldberg, 1989), 21 in potato (Heibges et al., 2003a,b), 31 in poplar (Philippe et al., 2009) and more than 11 in white clover (Islam et al., 2015a). The gene family generally encodes proteins of approximately $18-22 \mathrm{KDa}$ in size with a single reactive site (Laskowski and Kato, 1980). 
KPIs were originally proposed by Pusztai (1972) to function as storage proteins and this was later supported by other studies based on their occurrence in storage tissues like seed and tuber (Shewry et al., 1995; Shee and Sharma, 2008; Jørgensen et al., 2011). However, KPIs have been found to inhibit a range of proteinases like trypsin, chymotrypsin, elastase, subtilisin, cathepsin D and papain (Ritonja et al., 1990; Terada et al., 1994; Valueva et al., 2000; Heibges et al., 2003b; Major and Constabel, 2008) suggesting that, as a group, they have diverse proteinase targets. Indeed, the extensive range of in vitro inhibitory activities against different proteinases implies that KPIs have a wide range of in planta targets and functions. It was also suggested that KPIs act as a regulator of proteinases during germination and in defense-response during insect herbivory (Richardson et al., 1986; Xavier-Filho and Campos, 1989; Norton, 1991; Bauw et al., 2006; Hernández-Nistal et al., 2009). The activity of PIs including KPIs against insect digestive proteinases has led to the promotion of their use as tolerance determinants in transgenic plants (Green and Ryan, 1972; Hilder et al., 1987; Ryan, 1990; Jongsma and Bolter, 1997; Lee et al., 1999; McManus et al., 2005; Lima et al., 2011). Recent evidence also suggests that KPIs in plants are involved in programmed cell death, growth, and development (Karrer et al., 1998; Yeu et al., 2007; Kim et al., 2009; Laluk and Mengiste, 2011; Pereira et al., 2011; Boex-Fontvieille et al., 2015; Islam et al., 2015a). Moreover, changes in expression profile of KPIs in response to water limitation suggests a function for these proteins in abiotic stress, possibly by targeting specific proteinases and as such limiting their proteolytic activities (Downing et al., 1992; Kang et al., 2001; Desclos et al., 2008; Kidric et al., 2014).

To cope with water limitation, plants have evolved adaptive features and complex cellular signaling mechanisms to sense, respond, and survive (Shao et al., 2006; Bruce et al., 2007; Wu et al., 2007; Nakashima et al., 2009; Arbona et al., 2010; Harb et al., 2010; De Ollas et al., 2013). Although during stress phytohormone signaling pathways coordinate and integrate the whole plant response (Kreps et al., 2002; Bruce et al., 2007; Tardif et al., 2007; Wu et al., 2007), abscisic acid (ABA) plays a major role during drought (Fujita et al., 2011; Nakashima et al., 2014; Muñoz-Espinoza et al., 2015). ABA has been implicated in the early perception of water deficiency leading to the activation of stress-responsive genes and stimulation of stomatal closure to reduce water loss (Bray, 2002; Shinozaki et al., 2003; Xiong and Zhu, 2003; Verslues and Bray, 2006; Planchet et al., 2011). In addition, the involvement of ethylene (Et) has also been reported in drought-induced abscission as a mechanism to minimize water loss (Oh et al., 1997; Nikmatullah, 2009; Arraes et al., 2015). Recent studies also revealed that during abiotic stress, including water deficiency, ABA and Et act antagonistically where ABA limits Et production and associated inhibition of root elongation (Beaudoin et al., 2000; Sharp, 2002; Rosado et al., 2006; Wilkinson et al., 2012; Arraes et al., 2015). Another response to water stress is the accumulation of proline, which has been reported to act as tolerance factor in many plant species (McManus et al., 2000; Verdoy et al., 2006; Mattioli et al., 2008; Szabados and Savouré, 2010; Planchet et al., 2014). Several studies have also reported the association of ABA and proline accumulation in the model plant species Arabidopsis thaliana and Medicago truncatula during water stress (Strizhov et al., 1997; Szabados and Savouré, 2010; Planchet et al., 2011, 2014). However, independent of ABA and Et, many transcription factors and defense associated genes are also induced by water stress perception and play a role in stress adaptation or tolerance (Nakashima et al., 2014).

Both proteinases and proteinase inhibitors have been reported to be induced by water limiting conditions (Richards et al., 1994; Snowden et al., 1995; Fan and Wu, 2005; Shinozaki and Yamaguchi-Shinozaki, 2007; Yamaguchi et al., 2010; Kidric et al., 2014), though the hormonal control of this induction is unknown. The induced cellular proteolysis in water limitation is a complex process and it is difficult to establish a link between a specific group of proteinase and their corresponding inhibitor families (Degenkolbe et al., 2009; Simova-Stoilova et al., 2010; Mosolov and Valueva, 2011; Kidric et al., 2014). Among different PI families, cysteine PIs (cystatins) are widely studied in relation to water limitation (Doip et al., 2004; Zhang et al., 2008; Munger et al., 2012; Jangpromma et al., 2014; Quain et al., 2014; Kunert et al., 2015), whereas relatively little is known about the function of KPIs during water limitation (Downing et al., 1992; Kang et al., 2001).

Previously we described four phylogenetically distinct members of the KPI gene family from white clover (Trifolium repens L.; $\operatorname{Tr}-K P I$ ) and showed that a range of developmental and biotic stress-associated cues regulate their expression (Islam et al., 2015a,b). It was also shown that knock-down of these Tr-KPIs affected plant development, increased oxidative stress and revealed altered transcription of cellular signaling genes. The result suggested that for this gene family, a delicate regulation of $T r-K P I$ expression is required for the maintenance of a homeostasis critical for cell function. Therefore, we hypothesized that abiotic stress, such as water deficiency, also regulates the expression of $\operatorname{Tr}$-KPI gene family members and that their role in maintaining cellular homeostasis affect the plants' response to drought stress. In the current study, we have addressed the association of the KPI gene family as a stress-related factor during water limiting conditions in a non-model pasture plant species white clover. Using typical water deficiency and priming to a previous water deficiency, we showed that the expression of the members of $T r-K P I$ gene family were induced in distinct ways. The knock-down RNAi lines for the specific members of the gene family showed high proline accumulation in well-watered and water deficit condition with alteration of Et biosynthesis genes. The results suggest that the regulated expression of white clover $\operatorname{Tr}$-KPI genes is important during water limitation.

\section{MATERIALS AND METHODS}

\section{Plant Materials and Growth Conditions}

Two cultivars and one ecotype of white clover with different water requirements, namely, Kopu, Huia and Tienshan, were provided by AgResearch Grasslands, Palmerston North, New Zealand. The RNAi knock-down lines are described in Islam et al. (2015a) and are in the Huia background. The small-leaved white clover ecotype Tienshan is considered to display some 
drought tolerance; cv. Kopu with its large leaves is more drought susceptible; while cv. Huia with medium sized leaves is considered to be intermediate in terms of water requirement (Bosch et al., 1993; Hofmann et al., 2003; Hofmann and Jahufer, 2011). Plants arising from a single seed were selected randomly and maintained as stock plants. Clonal material for the experiments was taken from the stock plants as follows: the apical part of the stolon from the stock plants was excised just proximal to node four and all leaves were excised except the first emerged leaf. The stolon cuttings were then placed in pots containing vermiculite and were watered regularly with half strength Hoagland's solution (Gibeaut et al., 1997) and allowed to develop roots for at least 1 week. Healthy and morphologically similar rooted stolons were then transferred to soil. A single stolon was grown in a $5 \mathrm{~L}$ capacity pot for Tienshan and Kopu before transferring to environment-controlled rooms of the New Zealand Climate Environment Laboratory (NZCEL, Plant and Food Research, Palmerston North) as described by Nikmatullah (2009). The plants were grown for 1 week for acclimation before being subjected to water limiting conditions. For experiments with the 'Huia' cultivar and derived RNAi knock-down lines, a single four-noded stolon was grown in a 1:1 vermiculite:perlite mixture per pot to facilitate harvesting of roots for RNA extraction as it was difficult to remove attached soil particles from the root structure of soil-grown plants. The plants were grown in 1.2-L-capacity pots and were watered regularly with $0.5 \times$ Hoagland's solution at a plant growth room at Massey University. All plants were grown in a controlled temperature room at $22^{\circ} \mathrm{C}$ during the day and $14^{\circ} \mathrm{C}$ during the night, with a relative humidity $(\mathrm{RH})$ of $\sim 65 \%$ and a light intensity of $150 \mu \mathrm{E}$ over a $14 \mathrm{~h}$ photoperiod. All the plants, both before and during the treatment, were grown in controlled temperature rooms, as mentioned. Two sets of plants for the treatments were maintained separately in the controlled temperature room. Further, pots were moved every other day to minimize environmental variation due to placement of pots. While harvesting the leaf and root materials, the plants were selected randomly to eliminate any biasness. The development of RNAi knock-down lines for the four $\operatorname{Tr}$-KPIs namely $\operatorname{Tr}$-KPI1, $T r$-KPI2, $T r$-KPI4, and $T r$-KPI5 is described in detail in Islam et al. (2015a). The positive RNAi lines $\left(\mathrm{T}_{0}\right)$ and a number of non-expressing lines (designated as controls, C) were transferred to soil and maintained in a temperature-controlled containment glasshouse at $22^{\circ} \mathrm{C}$, with ambient light and humidity. These were used as stock plants for the RNAi and control lines from which clonal stolon cuttings were excised, as described above.

\section{Water Limitation Experiments}

To examine the involvement of $\operatorname{Tr}$-KPI gene family members in drought stress, two different water with-holding regimes were applied to either produce plants that were newly exposed to a water deficit or those that had first been pre-exposed (pre-conditioned) to a water deficit period: (i) a Non-PreStress (NPS) treatment consisting of a direct water withholding period and (ii) a PreStress (PS) treatment, consisting of 1 week of complete water withholding followed by 1 week of growth under well-watered conditions and then the second water withholding period. The second water withholding period coincided with the only water withholding period of the NPS-treated plants. For experiments with Tienshan and Kopu, moisture content of the media (soil) was measured daily using a Time Domain Reflectometer (TDR; Trase Soil Moisture Measuring System, Soilmoisture Equipment Corp., Santa Barbara, CA, United States) with $15 \mathrm{~cm}$ soil probes, during the only (NPS) or second (PS) water withholding period. For experiments with Huia and derived RNAi lines, the moisture content of vermiculite and perlite mixture was determined using the gravimetric method (Robinson, 1974) and was expressed as a percentage using the formula $\theta=(\mathrm{Ww}-\mathrm{Dw}) / \mathrm{Ww} \times 100$; where, $\mathrm{Ww}$ : is the wet weight of vermiculite:perlite mixture at the time of sampling; Dw: is the dry weight of the vermiculite: perlite mixture.

\section{Nucleic Acid Isolation}

For qRT-PCR, samples were collected daily until the moisture content dropped to approximately $9-10 \%$ for the soil grown plants Tienshan and Kopu and 32\% for both the PS and NPS treatments of vermiculite:perlite grown Huia. Total RNA was extracted from different samples using the Hot Borate method (Hunter and Reid, 2001; Moser et al., 2004). The RNA/DNA concentration was determined by measuring the absorbance at $260 \mathrm{~nm}\left(\mathrm{~A}_{260}\right)$ using a NanoDrop ND-1000 spectrophotometer V3.6 (Thermo Scientific, United States). Genomic DNA-free RNA samples were prepared according to the manufacturer's instructions using an RNase-free recombinant DNase treatment (Roche Applied Sciences, Roche Diagnostics GmbH, Mannheim, Germany). Total RNA $(2-10 \mu \mathrm{g})$ was mixed with $5 \mu \mathrm{L}$ of $10 \times$ incubation buffer and $1 \mu \mathrm{L}$ of DNase I (10 U), $1 \mu \mathrm{L}$ of Protector RNase Inhibitor $(10 \mathrm{U})$ and water to a final volume of $48.4 \mu \mathrm{L}$ and incubated at $37^{\circ} \mathrm{C}$ for $20 \mathrm{~min}$. The reaction was stopped by the addition of $1.6 \mu \mathrm{L}$ of $0.25 \mathrm{M}$ EDTA $\mathrm{pH} 8.0$ (to make a final concentration of $8 \mathrm{mM}$ ) and was heated at $75^{\circ} \mathrm{C}$ for $10 \mathrm{~min}$.

\section{Synthesis of cDNA and Quantitative Reverse-Transcription PCR (qRT-PCR)}

The Transcriptor First Strand cDNA synthesis kit (Roche Applied Sciences) was used to synthesize single strand DNA according to the manufacturer's instructions. In $0.2 \mathrm{~mL}$ capacity tubes, $1 \mu \mathrm{g}$ of total RNA was combined with Oligo $(\mathrm{dT})_{15}$ primer and the volume was adjusted with water to $13 \mu \mathrm{L}$. The mixture was denatured at $65^{\circ} \mathrm{C}$ for $10 \mathrm{~min}$ and subsequently placed on ice. Seven microliter of master reaction mixture (containing $5 \mathrm{X}$ transcriptor RT reaction buffer, $20 \mathrm{U} / \mu \mathrm{L}$ protector RNase inhibitor, $1 \mathrm{mM}$ dNTP-Mix and $10 \mathrm{U} / \mu \mathrm{L}$ transcriptor reverse transcriptase) was then added and cDNA synthesis was carried out at $55^{\circ} \mathrm{C}$ for $30 \mathrm{~min}$. Heat inactivation of Transcriptor Reverse Transcriptase was then performed at $85^{\circ} \mathrm{C}$ for $5 \mathrm{~min}$. For qRT-PCR analysis, gene specific primers were used as shown in Supplementary Table 1 . Two reference genes namely $T r-\beta$-actin and $\operatorname{Tr}-G A P D H$ were used for qRT-PCR. The standard curve method was used to determine the efficiency of all the primer sets (Ruijter et al., 2009). The cDNA samples were diluted 20 -fold using sterile water and qRT-PCR was performed using LightCycler ${ }^{\circledast} 480$ Real-Time PCR (Roche Applied Sciences). 
SYBR green I was used to monitor efficient DNA synthesis with three technical replicates for each 20 -fold diluted cDNA sample. Total volume of each reaction was $10 \mu \mathrm{L}$ consisting of $5 \mu \mathrm{L}$ of 2 X LightCycler ${ }^{\circledR} 480$ SYBR Green I Master Mix (Roche Applied Sciences), $2.5 \mu \mathrm{L}$ of 20 -fold diluted $\mathrm{cDNA}$ and $0.5 \mu \mathrm{L}$ of $10 \mu \mathrm{M}$ forward and reverse primers and $1.5 \mu \mathrm{L}$ of sterile water. PCR was performed using 96 well plates and the program was: $95^{\circ} \mathrm{C}$ for $5 \mathrm{~min}\left(95^{\circ} \mathrm{C} 10 \mathrm{~s}, 60^{\circ} \mathrm{C} 10 \mathrm{~s}, 72^{\circ} \mathrm{C} 10 \mathrm{~s}\right) \times 40$ cycles, $95^{\circ} \mathrm{C}$ melt and fluorescence measurements at $72^{\circ} \mathrm{C}$ for each cycle and continuously during final melting.

\section{Measurement of Proline Concentration}

The leaf proline content was measured according to the method of Magne and Larher (1992). Approximately 50-70 mg of powdered leaf tissue was suspended in $1.2 \mathrm{~mL}$ of $3 \%(\mathrm{w} / \mathrm{v})$ sulfosalicylic acid and the suspension was mixed vigorously using a vortex for approximately $30 \mathrm{~s}$. The cellular debris was subsequently pelleted by centrifugation at $20,800 \times g$ for $7 \mathrm{~min}$ at $4^{\circ} \mathrm{C}$. Five hundred microliter of supernatant was transferred to a glass tube and $500 \mu \mathrm{L}$ of water was added to a final volume of $1 \mathrm{~mL}$. Two milliliter of extraction reagent, containing Ninhydrin $(1 \% \mathrm{w} / \mathrm{v})$ in $60 \%(\mathrm{v} / \mathrm{v})$ glacial acetic acid, was then added to the tubes. The mixture was incubated in a water bath at $98^{\circ} \mathrm{C}$ for $1 \mathrm{~h}$, after which the reaction was stopped by cooling the tubes on ice. To extract proline, $3 \mathrm{~mL}$ of toluene was added and the tubes were vortexed for $30 \mathrm{~s}$ and were then allowed to stand for $5 \mathrm{~min}$ to separate the toluene phase (containing proline) from the rest of the supernatant. The upper phase was then transferred to a $3 \mathrm{~mL}$ glass cuvette and the absorbance was measured at $518 \mathrm{~nm}$ against a toluene blank.

\section{Statistical Analysis}

All the statistical analyses presented in this study were performed by SPSS 11.5 for Windows. Significance was tested using student's $t$-test and $P<0.05$ was considered as significant. For the qRT-PCR analysis for Tienshan and Kopu, pooled tissue from three independent plants, grown in individual pots was considered as a single biological replication. For wild type Huia cultivar plants, pooled tissue from four stolons of a single plant was considered as a biological replication. For the RNAi lines, pooled tissue from three genetically independent lines was considered as a biological replication. For each biological replication, qRT-PCR was repeated two or three times depending on the number of total samples for each experiment to minimize run to run and plate to plate variation. Relative transcript abundance was determined using the formula by Pfaffl (2001) and Pfaffl et al. (2004). For proline accumulation for the RNAi lines, pooled tissues from four genetically independent lines were used as a biological replication.

\section{RESULTS}

\section{Transcription of Tr-KPI Genes Is Inducible by Water Deficiency}

To measure the effect of water limitation on the transcription of $T r$-KPIs, we used white clover ecotype Tienshan, and two cultivars, Kopu and Huia, with different degrees of water requirements (Hofmann et al., 2003). Two treatments were applied to the plants: the first group designated as the NPS treatment directly received water deficit treatment. In the second group, designated as the PS treatment, the plants were subjected to a period of water deficiency followed by rehydration before exposure to the same water deficit period as the NPS treated plants.

First, $T r-K P I$ gene expression was measured in response to the NPS and PS treatments in soil grown Tienshan and Kopu plants (Figures 1A,B): both water limitation conditions induced Tr-KPI1 gene expression, but the transcript levels increased more in PS-treated plants. Transcript levels of Tr-KPI2 did not vary much in Tienshan and Kopu grown under both NPS and PS conditions (Figures 1A,B). However, the expression of $\operatorname{Tr}$-KPI5 was only highly induced (sixfold) in the more drought sensitive Kopu cultivar in response to the PS treatment (Figure 1B).

Next, Huia cultivar plants were grown on a defined vermiculite:perlite medium to allow isolation of RNA from root tissue. Here, Tr-KPI1 expression started to increase significantly from 53\% moisture content compared with the initial moisture content and with the NPS treatment (Figure 2A). However, $\operatorname{Tr}$-KPI2 expression increased significantly at 53 and $45.2 \%$, while the expression of Tr-KPI5 was fivefold induced in the PS treatment (Figures 2B,C). Furthermore, although the PS condition induced expression of the three $\operatorname{Tr}$-KPI genes in the leaf tissue of Huia, in the root tissue only Tr-KPI5 was induced, where a significant increase at $53 \%$ and an increasing trend at 45.2 and $30.6 \%$ ( $P$-value 0.08 and 0.06 , respectively) was observed when compared to the NPS treatment (Supplementary Figure 1D). These qRT-PCR results showed that expression of members of the $T r-K P I$ gene family, particularly $T r-K P I 1$ and $T r$-KPI5, increased during water limitation and the increase in transcript levels was stronger in response to the PS treatment.

\section{Water Deficiency Induces Physiological and Transcriptional Changes in White Clover}

As gene expression of three Tr-KPIs was induced in Huia, we used this variety for further study to determine additional responses of water limitation in NPS and PS treatments. Proline accumulation has been reported to increase under different environmental cues and it has been associated with metabolic changes during water deficit (Singh et al., 1972, 2000; Verbruggen and Hermans, 2008). Therefore, we measured the accumulaton of this amino acid in leaf tissue of plants grown under NPS and PS treatments. It was found that the NPS treatment resulted in significantly increased proline levels from $63 \%$ moisture content, while the PS treatment increased proline content from 53\% moisture content. Moreover, the NPS treatment caused more proline accumulation than the PS treatment up to $44 \%$ moisture content (Figure 3A).

Further, we studied the expression of key genes in the ABA and Et biosynthesis pathway during the NPS and PS treatment as markers for stress imposed to the plants. The 


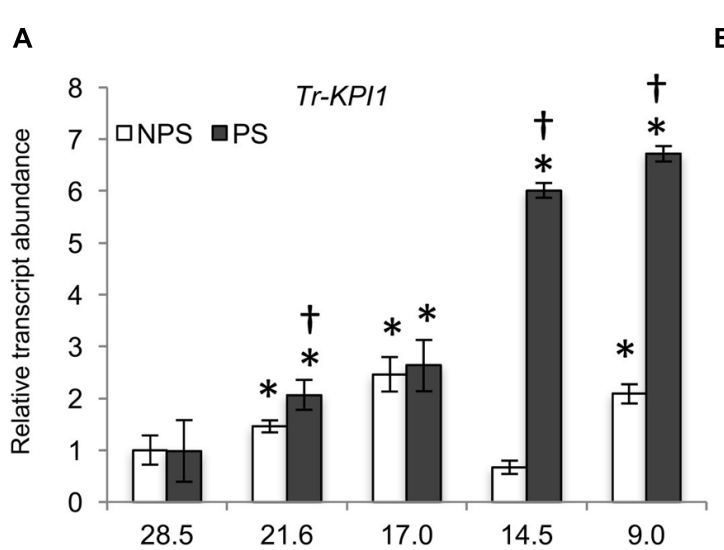

B
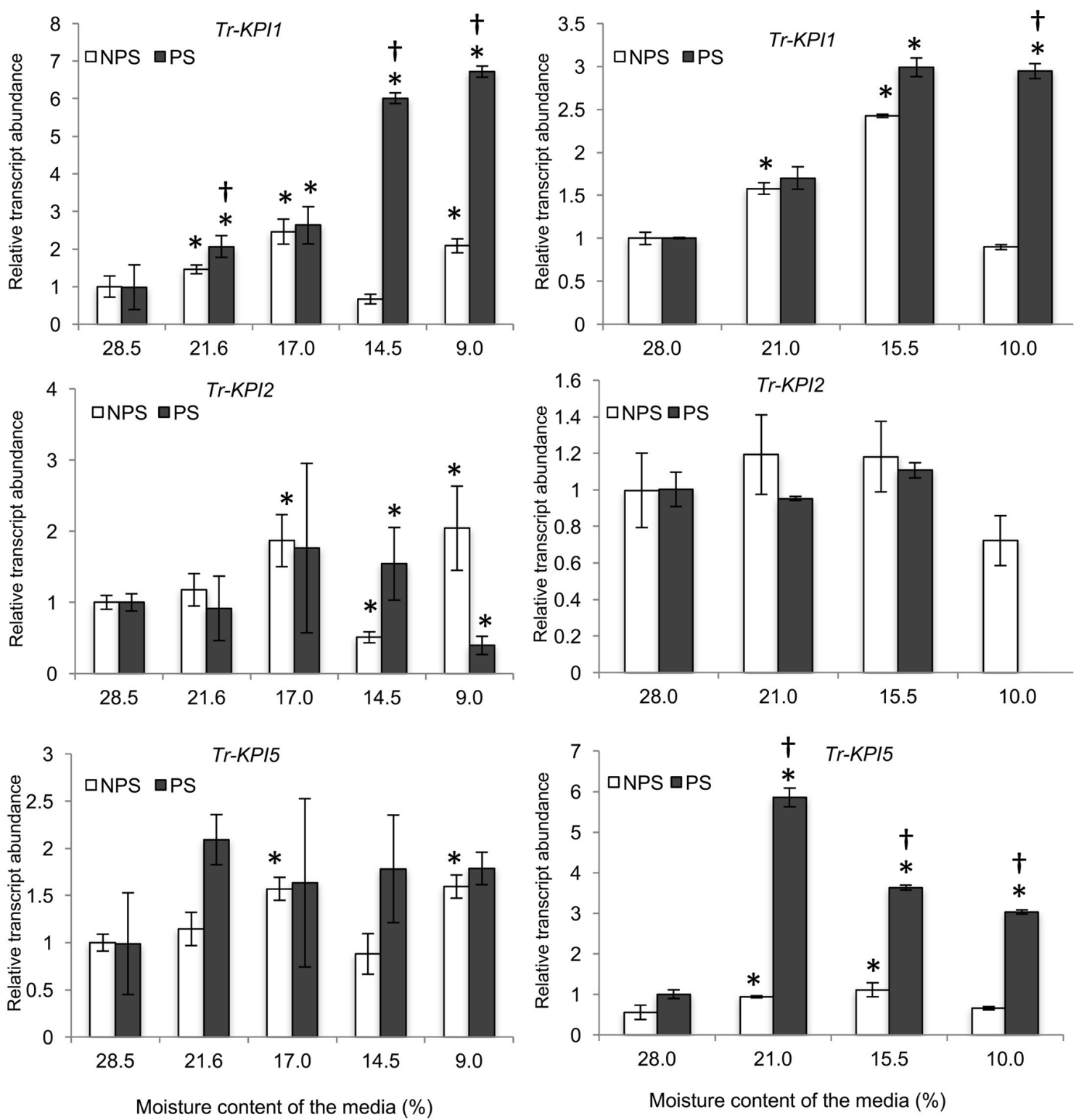

FIGURE 1 | Tr-KPI transcript abundance is responsive to water deficit treatment in white clover. Transcription of $T r-K P / 1, T r-K P I 2$, and $T r-K P / 5$ in the first fully expanded leaf (FFE) of white clover ecotype Tienshan (A) and cultivar Kopu (B), as indicated, under NPS and PS treatments. Relative transcript abundance was determined by qRT-PCR using two biological replicates, with pooled tissues collected from at least three individual plants comprising a biological replicate, and was normalized using two internal reference genes, $\operatorname{Tr}$ - $\beta$-actin and $\operatorname{Tr}$-GAPDH. The moisture content represent the mean value of the biological replicates and each data point represents mean value $\pm \mathrm{SE}$, of the biological replicates. Statistical analysis was performed using Student's $t$-test. ${ }^{*}$ Indicate statistically significant $(P<0.05)$ differential expression in comparison with initial moisture content for NPS and PS treatment, respectively, and ' ${ }^{\prime}$ ' indicates statistically significant $(P<0.05)$ expression in the PS treatment in comparison with the NPS treatments using Student's $t$-test.

expression of 9-cis-epoxycarotenoid dioxygenase 1 (NCED1) has been reported to correlate with the accumulation of ABA upon water limitation (Qin and Zeevaart, 1999; Deluc et al., 2009; Speirs et al., 2013) and here we studied transcript levels of $\operatorname{Tr}$-NCED1. Increased Tr-NCED1 levels were observed only in the NPS treatment where it was significantly higher from 61.2 to $30.6 \%$ moisture content (Figure 3B). We also studied the genes encoding Et biosynthesis enzymes 1-aminocyclopropane1-carboxylate (ACC) synthase (ACS) and ACC oxidase (ACO) (Supplementary Figure 2) as Et biosynthesis has been reported to increase upon water limitation (Apelbaum and Yang, 1981; Arraes et al., 2015). In the NPS treatment, a marginal significant increase was observed for $\operatorname{Tr}$-ACS1 at $45.2 \%$ and for $\operatorname{Tr}$-ACO1 at $30.6 \%$ moisture content (Supplementary Figure $2 \mathrm{~A}$ ). In the 


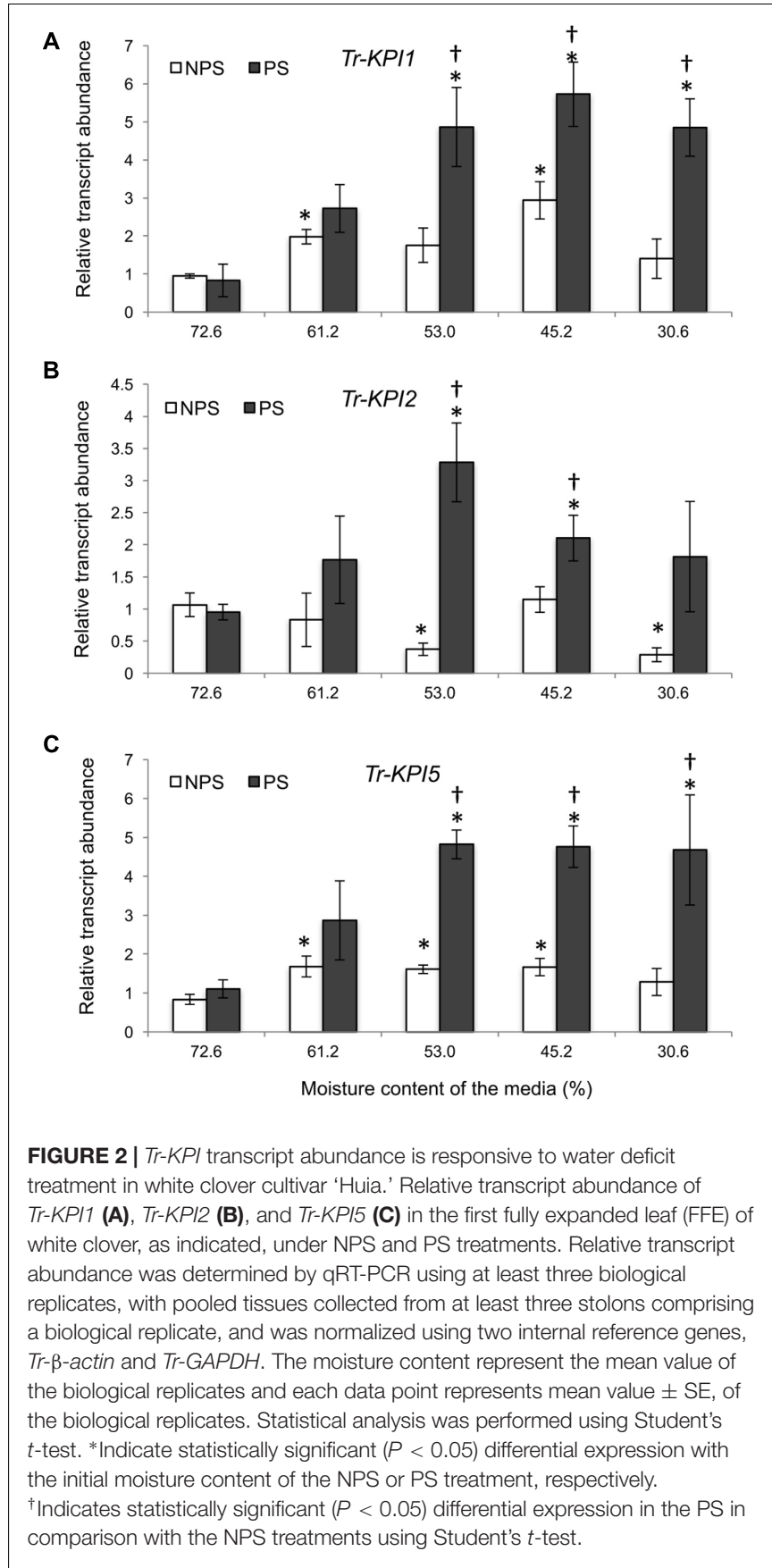

PS treatment, a decreasing trend was observed for $\operatorname{Tr}-A C S 1$ and $\operatorname{Tr}$-ACO2 while $\operatorname{Tr}$-ACO1 displayed a significant increase at $30.6 \%$ moisture content (Supplementary Figure 2B). The results showed that NPS treatment induced early proline accumulation and the transcription of Tr-NCED1 but affected Et biosynthesis genes only at lower moisture content levels. The results also suggest that a previous stress (PS treatment) prepared the plants for future stress, resulting in a lower proline accumulation without any significant up-regulation of ABA and limited up-regulation of Et biosynthesis genes ( $T r-A C O 1)$ during a subsequent drought period.
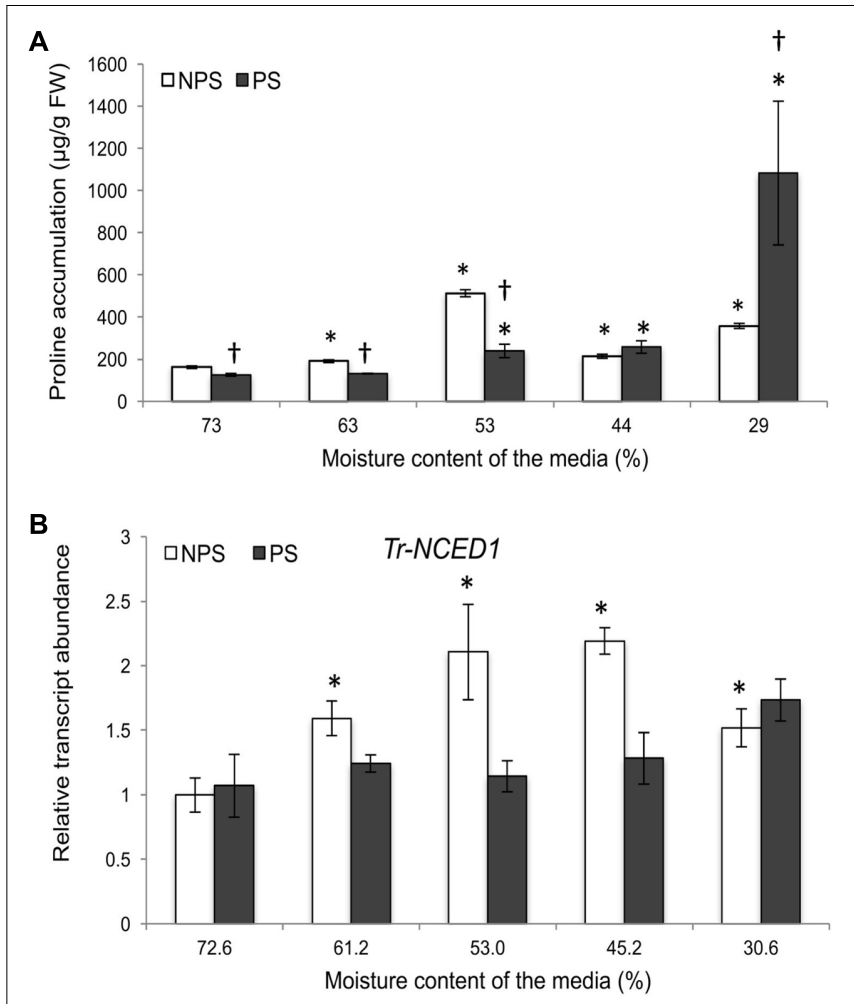

FIGURE 3 | Water deficit treatments in white clover induce Tr-NCED1 transcript upregulation and proline accumulation. Accumulation of L-Proline in wild type plant under PS and NPS treatments (A) and transcription of Tr-NCED1 (B), as indicated, in the first fully expanded (FFE) leaves in response to NPS and PS treatments against the moisture content of the media, as indicated. For $L$-proline accumulation, each value represents the mean from two biological replications each consisting of pooled tissues from four stolons. For Tr-NCED1, relative transcript abundance was determined by qRT-PCR using at least three biological replicates, with pooled tissues collected from at least three stolons comprising a biological replicate, and was normalized using two internal reference genes, $\operatorname{Tr}$ - $\beta$-actin and $\operatorname{Tr}$-GAPDH. The moisture content represent the mean value of the biological replicates and each data point represents mean value $\pm \mathrm{SE}$, of the biological replicates. Statistical analysis was performed using Student's $t$-test. ${ }^{*}$ Indicate statistically significant $(P<0.05)$ differential expression in comparison with initial moisture content for NPS and PS treatment, respectively, and ' + ' indicates statistically significant $(P<0.05)$ expression in the PS treatment in comparison with the NPS treatments using Student's $t$-test.

\section{Knock-Down of Tr-KPI Genes Result in Increased Proline Accumulation}

To ascertain the function of Tr-KPIs in water limiting conditions, RNAi lines for four $T r-K P I$ genes in the cultivar Huia were generated. These lines were called 35S::tr-kpi1, 35S::tr-kpi2 35S::tr-kpi4 and 35S::tr-kpi5 and are described in Islam et al. (2015a). For each construct, four independent lines were selected in which the targeted $\operatorname{Tr}$-KPI was most effectively knocked-down (Supplementary Figure 3; Islam et al., 2015a). Although the RNAi constructs were designed to specifically knock down the targeted genes, untargeted $\operatorname{Tr}-K P I$ genes were also affected: in the leaf tissue of the 35S::tr-kpi1 knock-down lines, the expression of $\operatorname{Tr}$-KPI1 was reduced to $7 \%, \operatorname{Tr}-K P I 2$ to $9 \%$ and $\operatorname{Tr}$-KPI5 to $40 \%$. 
In 35S::tr-kpi2 lines the expression of $T r$-KPI1 was reduced to 65\%; $\operatorname{Tr}$-KPI2 to $2 \%$ and $T r$-KPI5 by $76 \%$. Finally, in $35 S:: t r-k p i 5$ lines, the expression of $T r-K P I 1$ was reduced to $29 \%, T r-K P I 2$ to $18 \%$ and $\operatorname{Tr}$-KPI5 to $20 \%$ (Supplementary Figure 3; data was taken from Islam et al., 2015a). Nevertheless, the expression of $T r-K P I 1$ and $T r-K P I 2$ was lowest in their respective 35S::tr-kpi1 and 35S::tr-kpi2 lines while, in 35S::tr-kpi5 lines, expression of $\operatorname{Tr}$-KPI1, Tr-KPI2 and Tr-KPI5 genes decreased to $<30 \%$ of untransformed control lines.

The selected Tr-KPI knock-down lines and wild type control plants were grown under well-watered and PS water limiting conditions and we did not observe any obvious visible differences between the wild type and RNAi lines (data not shown). To determine the effect of Tr-KPI knock-down on proline levels, we first measured proline content in the leaf tissue of these RNAi lines grown in well-watered conditions (Figure 4A and Supplementary Figure 4). We observed that 35S::tr-kpi1 and 35S::tr-kpi5 plants displayed significantly increased proline levels, when grown in well-watered conditions, whereas 35S::tr-kpi2 and 35S::tr-kpi4 (a root specific KPI gene) lines did not show any change compared to control plants (Figure 4A and Supplementary Figure 4). We also measured proline accumulation during water limitation in the PS treatment for 35S::tr-kpil and 35S::tr-kpi5 plants. In the PS time course study, the initial proline content was significantly higher in 35S::tr-kpi5 lines when compared to the wild type plants. Nevertheless, both 35S::tr-kpi1 and 35S::tr-kpi5 plants displayed a significantly higher proline content compared to the wild type plants at 32\% moisture content (Figure 4B). These result show that the accumulation of proline in $35 S:: t r-k p i 1$ and 35 :: $t r-k p i 5$ lines is not a result of a water limiting condition per se but suggests an accentuated response in water limiting conditions.

\section{Knock-Down of Tr-KPI Genes Result in Increased Transcription of ET Biosynthesis Genes}

The accumulation of increased proline in the RNAi lines grown in well-watered and PS treatment suggested increased stress. Therefore, genes encoding enzymes involved in Et biosynthesis were examined. Both 35S::tr-kpi1 and 35S::tr-kpi5 plants displayed significantly increased transcript abundance of $\operatorname{Tr}$-ACS1 and $\operatorname{Tr}$-ACO1 genes compared to the control plants (Figures 5A,B). The expression of $\operatorname{Tr}$-ACS1 decreased gradually with the decrease in moisture content, while there was no change in the transcript levels of $\operatorname{Tr}$-ACO1 compared with the initial moisture content in both RNAi lines. In 35S::tr-kpi5 lines, the transcript abundance of Tr-ACO2 also remained significantly higher up to $33 \%$ moisture content as compared to the initial moisture content and to the control plants (Figure 5C). Therefore, 35S::tr-kpi5 lines responded more strongly than $35 S$ ::tr-kpil lines to water deficiency. The results suggest that the RNAi lines experience constitutive stress even in the absence of apparent adverse environmental conditions and that water deficiency enhanced the stress response.

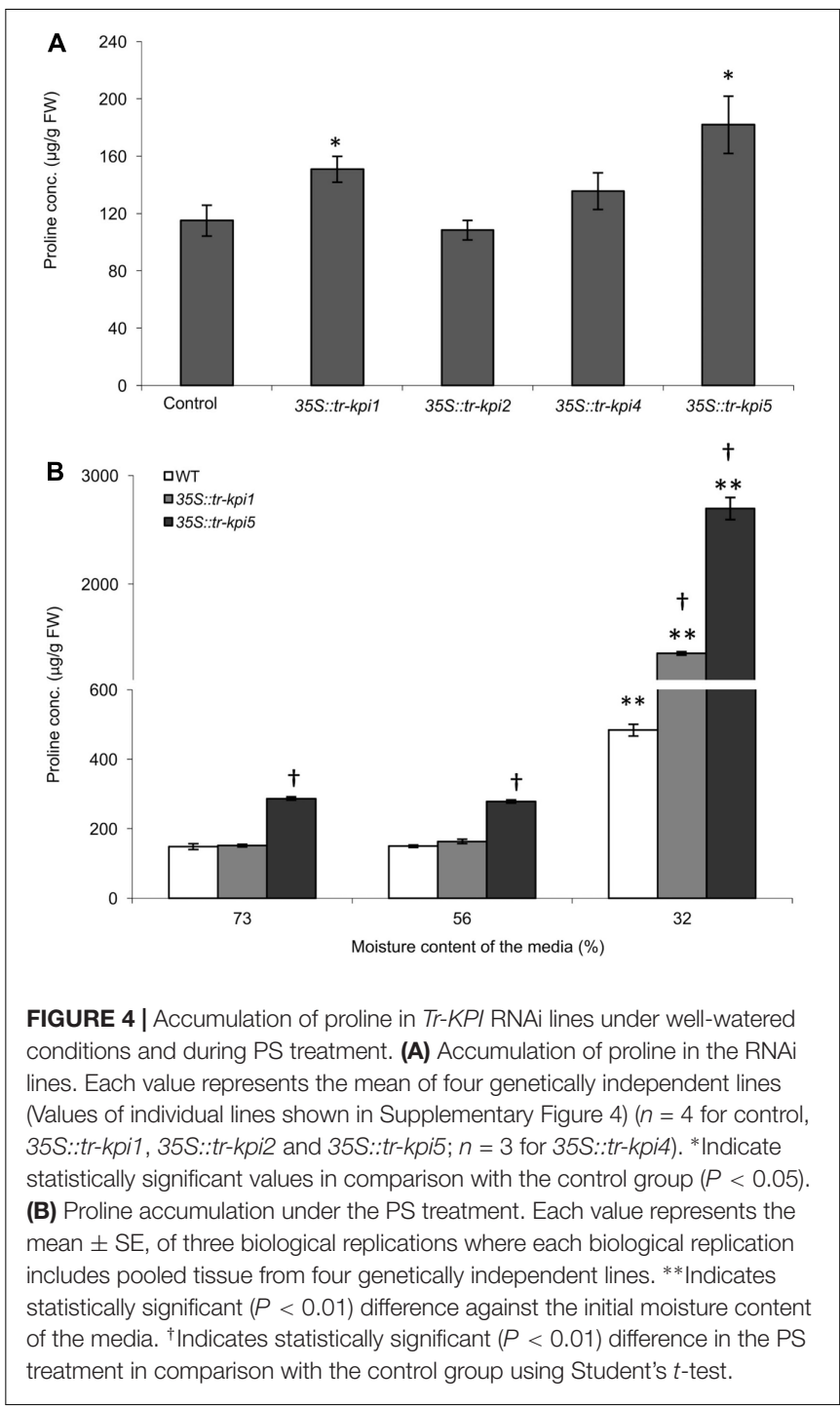

\section{DISCUSSION}

Kunitz proteinase inhibitors play vital roles in plant development and defense (Ryan, 1990; Mosolov and Valueva, 2011; BoexFontvieille et al., 2015; Islam et al., 2015a,b). We have previously suggested that specific white clover KPIs may exert their functions by maintaining cellular homeostasis and here we hypothesized that altered homeostasis may affect abiotic stress responses as well and that KPIs may function during drought stress. Therefore, we examined the function of KPI expression on white clover plants that were subjected to two distinct water withholding regimes. In the first NPS treatment, plants were subjected to a single water deficit period. In the second, PS treatment, plants were exposed to water deficit for a week followed by rehydration before being exposed to the same water deficit period as the NPS-treated plants. The PS treatment was performed with the aim to induce stress priming, which has been shown to result in a response that is earlier and stronger upon a successive biotic or abiotic stress treatment (Pastor et al., 2013; Borges et al., 2014). 


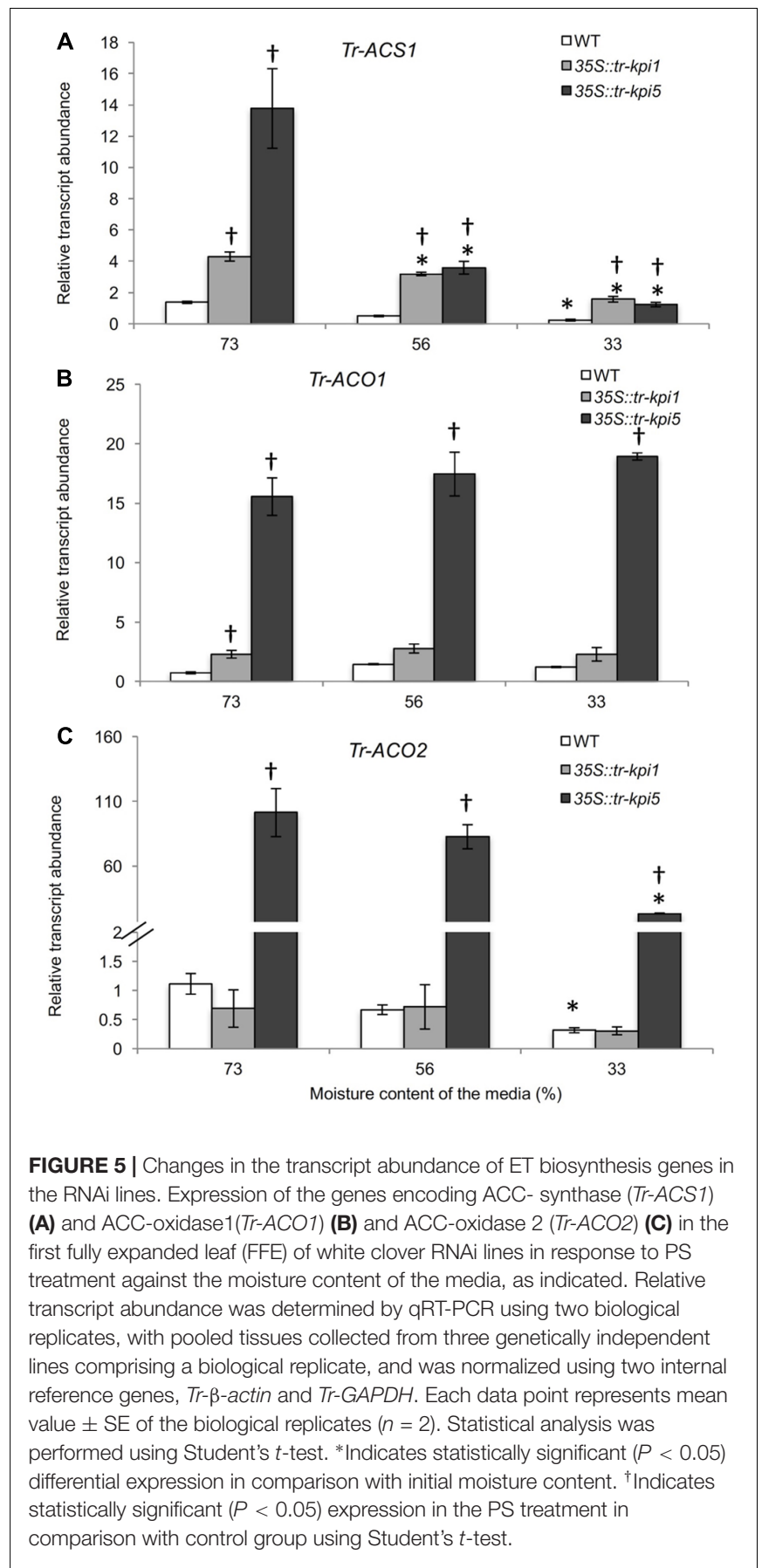

Over the course of the final or only water withholding treatment, several responses to water stress were measured in the plants: expression of the gene encoding the rate-determining enzyme in the ABA biosynthesis pathway, NCED1 (Tr-NCED1) was measured. In addition, expression of ACC synthase (Tr-ACS1) and ACC oxidase ( $T r$-ACO1 and $T r$-ACO2), encoding proteins involved in ET biosynthesis, was quantified and finally, proline accumulation was determined.

In NPS treated plants, the transcript levels of Tr-NCED1 significantly increased, suggesting that ABA biosynthesis was up-regulated (Figure 3). An increase in the transcript levels of Et biosynthesis gene $\operatorname{Tr}$-ACS1 and an early significant increase in proline accumulation was also observed (Figure 3 and Supplementary Figure 2). The up regulation of ABA and Et biosynthesis genes, together with proline accumulation during the NPS treatment suggests a stress response to water deficiency. In contrast, the PS treatment did not result in a change in $\operatorname{Tr}$-NCED1 transcript levels and a down-regulation of $\operatorname{Tr}-A C O 2$ was observed (Figure 3 and Supplementary Figure 2). Further, delayed as compared to NPS-treated plants, but significant accumulation of proline was detected in the PS treated leaf tissue (Figure 3). Therefore, stable $\operatorname{Tr}$-NCED1 expression in PS-treated plants suggests unchanged ABA biosynthesis and/or the involvement of other, as yet unidentified, members of the NCED gene family in ABA biosynthesis. Thus, the overall response in NPS treatment suggests a possible involvement of ABA-dependent pathway; whereas, the findings of the PS treatment are consistent with a greater drought tolerance and/or the involvement of an ABA-independent pathway to govern the drought response (Shinozaki and Yamaguchi-Shinozaki, 1997; Bray, 2002; Zhu, 2002; Shinozaki et al., 2003; Verslues and Bray, 2006; Planchet et al., 2011). Consequently, the findings of the PS treatment suggest a 'stress imprint' from a previous water deficiency that prevented the plants from having to bear the costs associated with triggering early proline accumulation and an ABA response (Conrath et al., 2006; Bruce et al., 2007; Walter et al., 2011).

As marked differences were observed in the NPS and PS treatment, we hypothesized that $\operatorname{Tr}-K P I$ gene expression would respond differently to NPS and PS treatments. In this study, we found that the expression of selected $T r-K P I$ genes was induced significantly in the NPS treatment in aboveground, but not in root tissues (Figures 1, 2 and Supplementary Figure 1). Our results are similar to findings of Kang et al. (2001) who reported that KPI-like proteins are induced by water deficiency and is broadly in agreement with data from Downing et al. (1992), who detected tissue specific expression of KPIs in Brassica napus leaves, but not in roots or seed. Nevertheless, we cannot exclude the possibility that other members of $\operatorname{Tr}-K P I$ gene family may respond to water deficiency in root tissue. In summary, the findings of the NPS treatment are in support of a role for Tr-KPIs in water deficiency.

Since the PS treatment resulted in a reduced stress response, we expected decreased induction of Tr-KPIs upon the second drought stress. Surprisingly we found that in the PS treatment the levels of Tr-KPIs transcripts were significantly induced, even in comparison with the NPS treatment. Of the three genes studied, Tr-KPI5 was most highly responsive in the more droughtsensitive varieties, signifying a possible function of this gene in water deficiency. These results are consistent with the idea that increased $T r-K P I$ expression may actually function as part of a mechanism that allow the plant to better cope with the drought stress, especially the second drought period of the PS treatment. Therefore, to examine the functional implication of transcriptional regulation of $T r-K P I s$, especially $T r$-KPI5 more directly in water deficiency, RNAi knock-down plants for the studied genes were developed in the Huia background. 
We have shown earlier that the leaves from the knockeddown plants displayed some stress-associated cellular signatures including an increase in $\mathrm{H}_{2} \mathrm{O}_{2}$ levels and a concurrent increase in SOD activity (Islam et al., 2015a). In this study, we observed that the 35S::tr-kpil and 35S::tr-kpi5 RNAi lines accumulated more proline than the wild type when grown in well-watered conditions. The higher proline accumulation may have a direct or indirect function in scavenging reactive oxygen species (ROS) (Alia et al., 2001; Liang et al., 2013; Signorelli et al., 2014; Zhang and Becker, 2015; Zhang et al., 2015). We found previously that Tr-NCED1 transcript levels remain unchanged in 35S::tr-kpi1 and 35S::tr-kpi5 lines compared to the controls during well-watered growth conditions (Islam et al., 2015a), suggesting that increased proline content in these plants are not related to the expression of $\operatorname{Tr}$-NCED1. Because the 35S::tr-kpi2 lines did not accumulate higher proline levels, the results eliminate the possibility that the increased proline levels in the 35S::tr-kpi1 and 35S::tr-kpi5 lines is the result of $T r-K P I 2$ knock-down. Nevertheless, the results suggest that the Tr-KPI1 and Tr-KPI5 knock-down plants experience constitutive stress. We employed a PS treatment to investigate the effect of $\operatorname{Tr}-K P I$ knock-down on the response to water deficiency. The 35S::tr-kpi5 RNAi lines accumulated significantly more proline in the PS treatment than the wild type, while higher proline levels in 35S::tr-kpi1 lines were only found at the lowest moisture level. Additionally, an increased transcription of Et biosynthesis genes were observed in the leaves of the RNAi lines, particularly of the Tr-KPI5 knocked-down lines (Figure 5). The induction of Et biosynthesis genes did not coincide with visible Et-induced senescence as we did not observe any visual yellowing of the treated plants (Oh et al., 1997; Arraes et al., 2015; data not shown). Therefore, the result suggests that upregulated transcription of Tr-KPI5 may function to better cope with drought stress in the drought-susceptible varieties. Hence, we propose that the increased proline accumulation in 35S::tr-kpi1 background resulted from the transcriptional suppression of Tr-KPI5 (Supplementary Figure 3). As the knockdown of $T r$-KPIs correspond with increased proline content in the RNAi plants, the results also reveal the correlation of upregulated expression of Tr-KPIs and reduced proline content in stress adapted PS-treated plants.

Previously, we reported that the transcription of $T r-K P I 1$ is highly responsive to biotic stress such as mechanical wounding and insect herbivory (Islam et al., 2015a). The knocked-down 35S::tr-kpi1 lines displayed the most marked reduction in herbivory feeding as shown by the retarded larval development compared to wild type plants and 35S::tr-kpi2 and 35S::tr-kpi5 lines. Instead, $T r$-KPI2 plays a central role in the development of white clover as the 35S::tr-kpi2 knocked-down lines produced shorter stolons and displayed reduced branching. The seven other members of the Tr-KPI gene family could have evolved to acquire different or overlapping functions in plant development and metabolism (Islam et al., 2015a). Therefore, we propose that members of the Tr-KPI multi-gene family have preferential functions in regulating cellular homeostasis and stress resistance such that $T r-K P I 1$ may function mainly as a result of biotic stress; $T r$-KPI2 during development and Tr-KPI5 in response to abiotic stress.
The current study highlighted that specific $T r-K P I$ genes are involved in water stress response and future studies should focus on the elucidation of the underlying molecular mechanism. Drought stress can cause a marked increase in cellular proteolytic activity in susceptible plants (Degenkolbe et al., 2009; SimovaStoilova et al., 2010; Mosolov and Valueva, 2011) and therefore, the wider $\operatorname{Tr}$-KPI gene family has the potential to regulate proteolysis during water deficiency. It is likely that $T r$-KPIs are functionally diverse and target different in planta proteinases. Although, KPI proteins were found to have different in vitro targets, including proteinases (Ritonja et al., 1990; Terada et al., 1994; Valueva et al., 2000; Heibges et al., 2003b; Major and Constabel, 2008), there is little known about the in planta targets of constitutively expressed KPIs because of the presence of a large number of proteinase coding genes in plants. For example, the Arabidopsis thaliana genome encodes over 800 proteinases which exemplifies the difficulty to identify the in planta PI targets (van der Hoorn, 2008). We showed in a previous study that total trypsin inhibitory activity was not altered in any of the RNAi lines which suggests limited, if any, significant induction of other functional Tr-KPI proteins. Nevertheless, water deficiency can induce various classes of proteinases (Seki et al., 2002; Bartels and Sunkar, 2005; Kidric et al., 2014) and therefore, finding the proteinase targets of the Tr-KPI family deserves more attention.

In summary, from the expressional analysis and use of knocked-down $\operatorname{Tr}$-KPI lines, we propose that particularly $T r$-KPI5 serves a central function under water limiting conditions in white clover. Therefore, these results are in support of our hypothesis that regulated expression of Tr-KPIs is of importance during water deficiency, possibly through alteration of cellular homeostasis. Our findings ascertain the involvement of the $\operatorname{Tr}$-KPI gene family in water stress and add to existing evidence that the function of KPIs is not solely restricted to one of storage protein or in response to biotic stress. Thus, we propose that the regulation of expression of the $T r-K P I$ gene family is part of an intrinsic mechanism by which critical cell functions are controlled under water limiting conditions: if such control is disrupted then changes to cellular homeostasis occur and major stress-response changes ensue.

\section{AUTHOR CONTRIBUTIONS}

AI jointly conceived the study, acquired and interpreted the data, wrote the manuscript and assisted with manuscript revision. SL and AN acquired and analyzed data and commented on the manuscript. PD assisted with data interpretation, manuscript writing, commented, reviewed and submitted the manuscript. MM jointly conceived the study, interpreted the data, commented on the results. All the authors have read and approved the final version of the manuscript.

\section{FUNDING}

This study was supported by a Massey University Doctoral Scholarship to AI. 


\section{ACKNOWLEDGMENTS}

We wish to thank Natalie Tiemens and Tina Sehrish for technical assistance with the water deficiency study for the RNAi lines. This manuscript is dedicated to the memory of MM.

\section{REFERENCES}

Alia, Mohanty, P., and Matysik, J. (2001). Effect of proline on the production of singlet oxygen. Amino Acids 21, 195-200. doi: 10.1007/s007260170026

Apelbaum, A., and Yang, S. F. (1981). Biosynthesis of stress ethylene induced by water deficit. Plant Physiol. 68, 594-596. doi: 10.1104/pp.68.3.594

Arbona, V., Argamasilla, R., and Gómez-Cadenas, A. (2010). Common and divergent physiological, hormonal and metabolic responses of Arabidopsis thaliana and Thellungiella halophila to water and salt stress. J. Plant Physiol. 167, 1342-1350. doi: 10.1016/j.jplph.2010.05.012

Arraes, F. B., Beneventi, M. A., Lisei de Sa, M. E., Paixao, J. F., Albuquerque, E. V., Marin, S. R., et al. (2015). Implications of ethylene biosynthesis and signaling in soybean drought stress tolerance. BMC Plant Biol. 15:213. doi: 10.1186/s12870-015-0597-Z

Bartels, D., and Sunkar, R. (2005). Drought and salt tolerance in plants. Crit. Rev. Plant Sci. 24, 23-58. doi: 10.1080/07352680590910410

Bauw, G., Nielsen, H. V., Emmersen, J., Nielsen, K. L., Jørgensen, M., and Welinder, K. G. (2006). Patatins, Kunitz protease inhibitors and other major proteins in tuber of potato cv. Kuras. FEBS J. 273, 3569-3584. doi: 10.1111/j.1742-4658. 2006.05364.x

Beaudoin, N., Serizet, C., Gosti, F., and Giraudat, J. (2000). Interactions between abscisic acid and ethylene signaling cascades. Plant Cell 12, 1103-1115. doi: 10.1105/tpc.12.7.1103

Boex-Fontvieille, E., Rustgi, S., Reinbothe, S., and Reinbothe, C. (2015). A Kunitztype protease inhibitor regulates programmed cell death during flower development in Arabidopsis thaliana. J. Exp. Bot. 66, 6119-6135. doi: 10.1093/ jxb/erv327

Borges, A. A., Jiménez-Arias, D., Expósito-Rodríguez, M., Sandalio, L. M., and Pérez, J. A. (2014). Priming crops against biotic and abiotic stresses: MSB as a tool for studying mechanisms. Front. Plant Sci. 5:642. doi: 10.3389/fpls.2014 00642

Bosch, J. V. D., Black, I. K., Cousins, G. R., and Woodfield, D. R. (1993). Enhanced drought tolerance in white clover. Proc. N Z Grass. Assoc. 55, 97-101.

Bray, E. A. (2002). Abscisic acid regulation of gene expression during water-deficit stress in the era of the Arabidopsis genome. Plant Cell Environ. 25, 153-161. doi: 10.1046/j.1365-3040.2002.00746.x

Bruce, T. J. A., Matthes, M. C., Napier, J. A., and Pickett, J. A. (2007). Stressful "memories" of plant: evidence and mechanisms. Plant Sci. 173, 603-608 doi: 10.1016/j.plantsci.2007.09.002

Conrath, U., Beckers, G. J. M., Flors, V., Garcia-Agustin, P., Jakab, G., Mauch, F., et al. (2006). Priming: getting ready for battle. Mol. Plant Microbe Interact. 19, 1062-1071. doi: 10.1094/MPMI-19-1062

De Ollas, C., Hernando, B., Arbona, V., and Gómez-Cadenas, A. (2013). Jasmonic acid transient accumulation is needed for abscisic acid increase in citrus roots under drought stress conditions. Physiol. Plant. 147, 296-306. doi: 10.1111/j. 1399-3054.2012.01659.x

Degenkolbe, B., Do, P. T., Zuther, E., Repsilber, D., Walther, D., Hincha, D. K., et al. (2009). Expression profiling of rice cultivars differing in their tolerance to long-term drought stress. Plant Mol. Biol. 69, 133-153. doi: 10.1007/s11103008-9412-7

Deluc, L. G., Quilici, D. R., Decendit, A., Grimplet, J., Wheatley, M. D., Schlauch, K. A., et al. (2009). Water deficit alters differentially metabolic pathways affecting important flavor and quality traits in grape berries of Cabernet Sauvignon and Chardonnay. BMC Genomics 10:212. doi: 10.1186/1471-216410-212

Desclos, M., Dubousset, L., Etienne, P., Le Caherec, F., Satoh, H., Bonnefoy, J., et al. (2008). A proteomic profiling approach to reveal a novel role of Brassica napus drought $22 \mathrm{kD} /$ water-soluble chlorophyll-binding protein in young leaves during nitrogen remobilization induced by stressful conditions. Plant Physiol. 147, 1830-1844. doi: 10.1104/pp.108.116905

\section{SUPPLEMENTARY MATERIAL}

The Supplementary Material for this article can be found online at: http://journal.frontiersin.org/article/10.3389/fpls.2017.01683/ full\#supplementary-material

Doip, N. N., Kidric, M., Repellin, A., Gareil, M., d'Arcy-Lameta, A., Pham Thi, A. T., et al. (2004). A multicystatin is induced by drought-stress in cowpea (Vigna unguiculata (L.) Walp) leaves. FEBS Lett. 577, 545-550. doi: 10.1016/j. febslet.2004.10.014

Downing, W. L., Mauxion, F., Fauvarque, M. O., Reviron, M. P., DeVienne, D., Vartanian, N., et al. (1992). A Brassica napus transcript encoding a protein related to the Künitz protease inhibitor family accumulates upon water stress in leaves, not in seeds. Plant J. 2, 685-693. doi: 10.1046/j.1365-313X.1992.t0111-00999.x

Fan, S. G., and Wu, G. J. (2005). Characteristics of plant proteinase inhibitors and their applications in combating phytophagous insects. Bot. Bull. Acad. Sin. 46, 273-292.

Fujita, Y., Fujita, M., Shinozaki, K., and Yamaguchi-Shinozaki, K. (2011). ABAmediated transcriptional regulation in response to osmotic stress in plants. J. Plant Res. 124, 509-525. doi: 10.1007/s10265-011-0412-3

Gibeaut, D. M., Hulett, J., Cramer, G. R., and Seemann, J. R. (1997). Maximal biomass of Arabidopsis thaliana using a simple, low-maintenance hydroponic method and favorable environmental conditions. Plant Physiol. 115, 317-319. doi: 10.1104/pp.115.2.317

Green, T. R., and Ryan, C. A. (1972). Wound-induced proteinase inhibitor in plant leaves: a possible defense mechanism against insects. Science 175, 776-777. doi: $10.1126 /$ science.175.4023.776

Harb, A., Krishnan, A., Ambavaram, M. M. R., and Pereira, A. (2010). Molecular and physiological analysis of drought stress in Arabidopsis reveals early responses leading to acclimation in plant growth. Plant Physiol. 154, 1254-1271. doi: $10.1104 / p p .110 .161752$

Heibges, A., Glaczinski, H., Ballvora, A., Salamini, F., and Gebhardt, C. (2003a). Structural diversity and organization of three gene families for Kunitz type enzyme inhibitors from potato tubers (Solanum tuberosum L.). Mol. Genet. Genomics 269, 526-534.

Heibges, A., Salamini, F., and Gebhardt, C. (2003b). Functional comparison of homologous members of three groups of Kunitz-type enzyme inhibitors from potato tubers (Solanum tuberosum L.). Mol. Genet. Genomics 269, 535-541.

Hernández-Nistal, J. H., Martín, I., Jiménez, T., Dopico, B., and Labrador, E. (2009). Two cell wall Kunitz trypsin inhibitors in chickpea during seed germination and seedling growth. Plant Physiol. Biochem. 47, 181-187. doi: 10.1016/j.plaphy.2008.11.009

Hilder, V. A., Gatehouse, A. M. R., Sheerman, S. E., Barker, R. F., and Boulter, D. (1987). A novel mechanism of insect resistance engineered into tobacco. Nature 330, 160-163. doi: 10.1038/330160a0

Hofmann, R. W., Campbell, B. D., Bloor, S. J., Swinny, E. E., Markham, K. R. Ryan, K. G., et al. (2003). Responses to UV-B radiation in Trifolium repens L. - physiological links to plant productivity and water availability. Plant Cell Environ. 26, 603-612. doi: 10.1111/j.1438-8677.2011.00458.x

Hofmann, R. W., and Jahufer, M. Z. Z. (2011). Tradeoff between biomass and flavonoid accumulation in white clover reflects contrasting plant strategies. PLOS ONE 6:e18949. doi: 10.1371/journal.pone.0018949

Hunter, D. A., and Reid, M. S. (2001). A simple and rapid method for isolating high quality RNA from flower petals. Acta Hortic. 543, 147-152. doi: 10.17660/ ActaHortic.2001.543.18

Islam, A., Leung, S., Burgess, E. P., Laing, W. A., Richardson, K. A., Hofmann, R. W., et al. (2015a). Knock-down of transcript abundance of a family of Kunitz proteinase inhibitor genes in white clover (Trifolium repens) reveals a redundancy and diversity of gene function. New Phytol. 208, 1188-1201. doi: $10.1111 /$ nph.13543

Islam, A., Mercer, C. F., Leung, S., Dijkwel, P. P., and McManus, M. T. (2015b). Transcription of biotic stress associated genes in white clover (Trifolium repens L.) differs in response to cyst and root-knot nematode infection. PLOS ONE 109:e0137981. doi: 10.1371/journal.pone.0137981 
Jangpromma, N., Saito, A., Araki, T., Jaisil, P., Songsri, P., Daduang, S., et al. (2014). Molecular cloning and characterization in eukaryotic expression systems of a sugarcane cysteine protease inhibitor gene involved in drought tolerance. Turk. J. Bot. 38, 724-736. doi: 10.3906/bot-1310-46

Jofuku, K. D., and Goldberg, R. B. (1989). Knutiz trypsin inhibitors genes are differentially expressed during the soybean life cycles and in transformed tobacco plants. Plant Cell 1, 1079-1093. doi: 10.1105/tpc.1.11.1079

Jongsma, M. A., and Bolter, C. J. (1997). The adaptation of insects to plant protease inhibitors. J. Insect Physiol. 43, 885-896. doi: 10.1016/S0022-1910(97)00040- 1

Jørgensen, M., Stensballe, A., and Welinder, K. G. (2011). Extensive posttranslational processing of potato tuber storage proteins and vacuolar targeting. FEBS J. 278, 4070-4087. doi: 10.1111/j.1742-4658.2011.08311.x

Kang, S., Choi, J., and Suh, S. (2001). A leaf-specific 27kda protein of potato kunitztype proteinase inhibitor is induced in response to abscisic acid, ethylene, methyl jasmonate and water deficit. Mol. Cells 13, 144-147.

Karrer, E. E., Beachy, R. N., and Holt, C. A. (1998). Cloning of tobacco genes that elicit the hypersensitive response. Plant Mol. Biol. 36, 681-690. doi: 10.1023/A: 1005949304445

Kidric, M., Kos, J., and Sabotic, J. (2014). Proteases and their endogenous inhibitors in the plant response to abiotic stress. Bot. Serb. 38, 139-158.

Kim, J., Baek, S. A., and Im, K. H. (2009). Overexpression of a Kunitz-type trypsin inhibitor (AtKTI1) causes early flowering in Arabidopsis. Plant Growth Regul. 59, 75-81. doi: 10.1007/s10725-009-9389-5

Kreps, J. A., Wu, Y., Chang, H. S., Zhu, T., Wang, X., and Harper, J. F. (2002). Transcriptome changes for Arabidopsis in response to salt, osmotic, and cold stress. Plant Physiol. 130, 2129-2141. doi: 10.1104/pp.008532

Kunert, K. J., van Wyk, S. J., Cullis, C. A., Vorster, B. J., and Foyer, C. H. (2015). Potential use of phytocystatins in crop improvement, with a particular focus on legumes. J. Exp. Bot. 66, 3559-3570. doi: 10.1093/jxb/erv211

Laluk, K., and Mengiste, T. (2011). The Arabidopsis extracellular UNUSUAL SERINE PROTEASE INHIBITOR functions in resistance to necrotrophic fungi and insect herbivory. Plant J. 68, 480-494. doi: 10.1111/j.1365-313X.2011. 04702.x

Laskowski, M., and Kato, I. (1980). Protein inhibitors of proteinases. Annu. Rev. Biochem. 49, 593-626. doi: 10.1146/annurev.bi.49.070180.003113

Lee, S. I., Lee, S. H., Koo, J. C., Chun, H. J., Lim, C. O., Mun, J. H., et al. (1999). Soybean Kunitz trypsin inhibitor (SKTI) confers resistance to the brown plant hopper (Nilaparvata lugens Stal) in transgenic rice. Mol. Breed. 5, 1-9. doi: 10.1023/A:1009660712382

Liang, X., Zhang, L., Natarajan, S. K., and Becker, D. F. (2013). Proline mechanisms of stress survival. Antioxid. Redox Signal. 19, 998-1011. doi: 10.1089/ars.2012. 5074

Lima, T. B., Silva, O. N., Migliolo, L., Souza-Filho, C., Goncalves, E. G., Vasconcelos, I. M., et al. (2011). A Kunitz proteinase inhibitor from corms of Xanthosoma blandum with bactericidal activity. J. Nat. Prod. 74, 969-975. doi: $10.1021 / \mathrm{np} 200312 \mathrm{r}$

Magne, C., and Larher, F. (1992). High sugar content of the extracts interferes of colorimetric determination of amino acids and free proline. Anal. Biochem. 200, 115-118. doi: 10.1016/0003-2697(92)90285-F

Major, I. T., and Constabel, C. P. (2008). Functional analysis of the Kunitz Trypsin Inhibitor family in Poplar reveals biochemical diversity and multiplicity in defense against herbivores. Plant Physiol. 146, 888-903. doi: 10.1104/pp.107. 106229

Mattioli, R., Marchese, D., D’Angeli, S., Altamura, M. M., Costantino, P., and Trovato, M. (2008). Modulation of intracellular proline levels affects flowering time and inflorescence architecture in Arabidopsis. Plant Mol. Biol. 66, 277-288. doi: 10.1007/s11103-007-9269-1

McManus, M. T., Bieleski, R. L., Caradus, J. R., and Barker, D. J. (2000). Pinitol accumulation in mature leaves of white clover in response to a water deficit. Environ. Exp. Bot. 43, 11-13. doi: 10.1016/S0098-8472(99)00 041-6

McManus, M. T., Laing, W. A., Watson, L. M., Markwick, N., Voisey, C. R., and White, D. W. R. (2005). Expression of the soybean (Kunitz) trypsin inhibitor in leaves of white clover (Trifolium repens L.). Plant Sci. 168, 1211-1220. doi: $10.1016 /$ j.plantsci.2004.12.020

Moser, C., Gatto, P., Moser, M., Pindo, M., and Velaso, R. (2004). Isolation of functional RNA from small amounts of different grape and apple tissues. Mol. Biotechnol. 26, 95-99. doi: 10.1385/MB:26:2:95
Mosolov, V. V., and Valueva, T. A. (2011). Inhibitors of proteolytic enzymes under abiotic stresses in plants (Review). Appl. Biochem. Microbiol. 47, 453-459. doi: 10.1134/S0003683811050097

Munger, A., Coenen, K., Cantin, L., Goulet, C., Vaillancourt, L. P., Goulet, M. C., et al. (2012). Beneficial 'unintended effects' of a cereal cystatin in transgenic lines of potato, Solanum tuberosum. BMC Plant Biol. 12:198. doi: 10.1186/14712229-12-198

Muñoz-Espinoza, V. A., López-Climent, M. F., Casaretto, J. A., and GómezCadenas, A. (2015). Water stress responses of tomato mutants impaired in hormone biosynthesis reveal abscisic acid, jasmonic acid and salicylic acid interactions. Front. Plant Sci. 6:997. doi: 10.3389/fpls.2015.00997

Nakashima, K., Ito, Y., and Yamaguchi-Shinozaki, K. (2009). Transcriptional regulatory networks in response to abiotic stresses in Arabidopsis and grasses. Plant Physiol. 149, 88-95. doi: 10.1104/pp.108.129791

Nakashima, K., Yamaguchi-Shinozaki, K., and Shinozaki, K. (2014). The transcriptional regulatory network in the drought response and its crosstalk in abiotic stress responses including drought, cold, and heat. Front. Plant Sci. 5:170. doi: 10.3389/fpls.2014.00170

Nikmatullah, A. (2009). Regulation of Ethylene Biosynthesis in Vegetative Tissues of White Clover (Trifolium repens L.) During Water Deficit. Doctoral thesis, Massey University, Palmerston North.

Norton, G. (1991). "Proteinase Inhibitors," in Toxic Substances in Crop Plants, eds J. P. F. D’Mello, C. M. Duffus, and J. H. Duffus (London: The Royal Society of Chemistry), 68-106. doi: 10.1533/9781845698454.68

Oh, S. A., Park, J.-H., Lee, G. I., Paek, K. H., Park, S. K., and Nam, G. H. (1997). Identification of three genetic loci controlling leaf senescence in Arabidopsis thaliana. Plant J. 12, 527-535. doi: 10.1046/j.1365-313X.1997. 00527.x

Pastor, V., Luna, E., Mauch-Mani, B., Ton, J., and Flors, V. (2013). Primed plants do not forget. Environ. Exp. Bot. 94, 46-56. doi: 10.1016/j.envexpbot.2012. 02.013

Pereira, K. R. B., Botelho-Júnior, S., Domingues, D. P., Machado, O. L. T., Oliveira, A. E. A., Fernandes, K. V. S., et al. (2011). Passion fruit flowers: Kunitz trypsin inhibitors and cystatin differentially accumulate in developing buds and floral tissues. Phytochemistry 72, 1955-1961. doi: 10.1016/j.phytochem.2011. 06.009

Pfaffl, M. W. (2001). A new mathematical model model for relative quantification in real-time RT-PCR. Nucleic Acids Res. 29, 2002-2007. doi: 10.1093/nar/29. 9.e45

Pfaffl, M. W., Tichopad, A., Prgomet, C., and Neuvians, T. P. (2004). Determination of stable housekeeping genes, differentially regulated target genes and sample integrity: BestKeeper-Excel-based tool using pair-wise correlations. Biotechnol. Lett. 26, 509-551. doi: 10.1023/B:BILE.0000019559.84305.47

Philippe, R. N., Ralph, S. G., Külheim, C., Jancsik, S. I, and Bohlmann, J. (2009). Poplar defense against insects: genome analysis, full-length cDNA cloning, and transcriptome and protein analysis of the poplar Kunitz-type protease inhibitor family. New Phytol. 184, 865-884. doi: 10.1111/j.1469-8137.2009. 03028.x

Planchet, E., Rannou, O., Ricoult, C., Boutet-Mercey, S., Maia-Grondard, A., and Limami, A. M. (2011). Nitrogen metabolism responses to water deficit act through both abscisic acid (ABA)-dependent and independent pathways in Medicago truncatula during post-germination. J. Exp. Bot. 62, 605-615. doi: $10.1093 /$ jxb/erq294

Planchet, E., Verdu, I., Deladaie, J., Cukier, C., Girard, C., Paven, M. C. M., et al. (2014). Abscisic acid-induced nitric oxide and proline accumulation in independent pathways under water-deficit stress during seedling establishment in Medicago truncatula. J. Exp. Bot. 65, 2161-2170. doi: 10.1093/jxb/ eru088

Pusztai, A. (1972). Metabolism of trypsin inhibitory proteins in the germinating seeds of kidney bean (Phaseolus vulgaris). Planta 107, 121-129. doi: 10.1007/ BF00387718

Qin, X., and Zeevaart, J. A. D. (1999). The 9-cis-epoxycarotenoid cleavage reaction is the key regulatory step of abscisic acid biosynthesis in water-stressed bean. Proc. Natl. Acad. Sci. U.S.A. 96, 15354-15361. doi: 10.1073/pnas.96.26. 15354

Quain, M. D., Makgopa, M. E., Márquez-García, B., Comadira, G., FernandezGarcia, N., Olmos, E., et al. (2014). Ectopic phytocystatin expression leads to enhanced drought stress tolerance in soybean (Glycine max) and Arabidopsis 
thaliana through effects on strigolactone pathways and can also result in improved seed traits. Plant Biotechnol. J. 12, 903-913. doi: 10.1111/pbi.12193

Rawlings, N. D., Barrett, A. J., and Finn, R. D. (2016). Twenty years of the MEROPS database of proteolytic enzymes their substrates and inhibitors. Nucleic Acids Res. 44, D343-D350. doi: 10.1093/nar/gkv1118

Richards, K. D., Snowden, K. C., and Gardner, R. C. (1994). Wali6 and wali7: genes induced by aluminium in wheat (Triticum aestivum L.) roots. Plant Physiol. 105, 1455-1456. doi: 10.1104/pp.105.4.1455

Richardson, M., Campos, F. A. P., Xavier-Filho, J., Macedo, M. L. R., Maia, G. M. C., and Yarwood, A. (1986). The amino acid sequence and reactive (inhibitory) site of the major trypsin inhibitor (DE5) isolate from seeds of the Brazilian carolina tree (Adenanthera pavonina L.). Biochim. Biophys. Acta 872, 134-140. doi: 10.1016/0167-4838(86)90156-1

Ritonja, A., Krizaj, I., Mesko, P., Kopitar, M., Lucovnik, P., Strukelj, B., et al. (1990). The amino acid sequence of a novel inhibitor of cathepsin D from potato. FEBS Lett. 267, 13-15. doi: 10.1016/0014-5793(90)80275-N

Robinson, D. A. (1974). A note on the expression of soil moisture content. Area 6, 9-13.

Rosado, A., Amaya, I., VAlpuesta, V., Cuartero, J., Botella, M. A., and Borsani, O. (2006). ABA- and ethylene-mediated responses in osmotically stressed tomato are regulated by the TSS2 and TOS1 loci. J. Exp. Bot. 57, 3327-3335. doi: $10.1093 /$ jxb/erl094

Ruijter, J. M., Ramakers, C., Hoogaars, W. M. H., Karlen, Y., Bakker, O., van den Hoff, M. J. B., et al. (2009). Amplification efficiency: linking baseline and bias in the analysis of quantitative PCR data. Nucleic Acids Res. 37:e45. doi: 10.1093/nar/gkp045

Ryan, C. A. (1990). Protease inhibitors in plants: genes for improving defenses against insects and pathogens. Annu. Rev. Phytopathol. 28, 425-449. doi: 10.1146/annurev.py.28.090190.002233

Seki, M., Narusaka, M., Ishida, J., Nanjo, T., Fujita, M., Oono, Y., et al. (2002). Monitoring the expression profiles of 7000 Arabidopsis genes under drought, cold and high- salinity stresses using a full-length cDNA microarray. Plant $J$. 31, 279-292. doi: 10.1046/j.1365-313X.2002.01359.x

Shao, H. B., Chu, L. Y., Zhao, C. X., Guo, Q. J., Liu, X. A., and Ribaut, J. M. (2006). Plant gene regulatory network system under abiotic stress. Acta Biol. Szeged. $50,1-9$.

Sharp, R. E. (2002). Interaction with ethylene: changing views on the role of abscisic acid in root and shoot growth responses to water stress. Plant Cell Environ. 25, 211-222. doi: 10.1046/j.1365-3040.2002.00798.x

Shee, C., and Sharma, A. K. (2008). Storage and affinity properties of Murraya koenigii trypsin inhibitor. Food Chem. 107, 312-319. doi: 10.1016/j.foodchem. 2007.08.020

Shewry, P. R., Napier, J. A., and Tatham, A. S. (1995). Seed storage proteins: structures 'and biosynthesis. Plant Cell 7, 945-956. doi: 10.1105/tpc.7.7.945

Shinozaki, K., and Yamaguchi-Shinozaki, K. (1997). Gene expression and signal transduction in water-stress response. Plant Physiol. 115, 327-334. doi: 10.1104/ pp.115.2.327

Shinozaki, K., and Yamaguchi-Shinozaki, K. (2007). Gene networks involved in drought stress response and tolerance. J. Exp. Bot. 58, 221-227. doi: 10.1093/ jxb/erl164

Shinozaki, K., Yamaguchi-Shinozaki, K., and Seki, M. (2003). Regulatory network of gene expression in the drought and cold stress responses. Curr. Opin. Plant Biol. 6, 410-417. doi: 10.1016/S1369-5266(03)00092-X

Signorelli, S., Coitino, E. L., Borsani, O., and Monza, J. (2014). Molecular mechanisms for the reaction between $\mathrm{OH}$ radicals and proline: insights on the role as reactive oxygen species scavenger in plant stress. J. Phys. Chem. B 118, 37-47. doi: 10.1021/jp407773u

Simova-Stoilova, L., Vaseva, I., Grigorova, B., Demirevska, K., and Feller, U. (2010). Proteolytic activity and cysteine protease expression in wheat leaves under severe soil drought and recovery. Plant Physiol. Biochem. 48, 200-206. doi: 10.1016/j.plaphy.2009.11.003

Singh, D. K., Peter, W. G. S., Charles, K. P., and Vijaya, S. (2000). Role of proline and leaf expansion rate in the recovery of stressed white clover leaves with increased phosphorus concentration. New Phytol. 146, 261-269. doi: 10.1046/ j.1469-8137.2000.00643.x

Singh, T. N., Aspinall, D., and Paleg, L. G. (1972). Proline accumulation and varietal adaptability to drought in barley: a potential metabolic measure of drought resistance. Nat. New Biol. 236, 188-190. doi: 10.1038/newbio236188a0
Snowden, K. C., Richards, K. D., and Gardner, R. C. (1995). Aluminum induced genes. Plant Physiol. 107, 341-348. doi: 10.1104/pp.107.2.341

Speirs, J., Binney, A., Collin, M., Edwards, E., and Loveys, B. (2013). Expression of $\mathrm{ABA}$ synthesis and metabolism genes under different irrigation strategies and atmospheric VPDs is associated with stomatal conductance in grapevine (Vitis vinifera L. cv Cabernet Sauvignon). J. Exp. Bot. 64, 1907-1916. doi: 10.1093/jxb/ ert052

Strizhov, N., Abraham, E., Okresz, L., Blickling, S., Zilberstein, A., Schell, J., et al. (1997). Differential expression of two P5CSgenes controlling proline accumulation during salt stress requires ABA and is regulated by ABA1, ABI1 and AXR2 in Arabidopsis. Plant J. 12, 557-569. doi: 10.1046/j.1365-313X.1997. 00557.x

Szabados, L., and Savouré, A. (2010). Proline: a multifunctional amino acid. Trends Plant Sci. 15, 89-97. doi: 10.1016/j.tplants.2009.11.009

Tardif, G., Kane, N. A., Adam, H., Labrie, L., Major, G., Gulick, P., et al. (2007). Interaction network of proteins associated with abiotic stress response and development in wheat. Plant Mol. Biol. 63, 703-718. doi: 10.1007/s11103-0069119-6

Terada, S., Fujimura, S., Katayama, H., Nagasawa, M., and Kimoto, E. (1994). Purification and characterization of two Kunitz family subtilisin inhibitors from seeds of Canavalia lineata. J. Biochem. 115, 392-396. doi: 10.1093/ oxfordjournals.jbchem.a124349

Valueva, T. A., Revina, T. A., Mosolov, V. V., and Mentele, R. (2000). Primary structure of potato Kunitz-type serine proteinase inhibitor. Biol. Chem. 381, 1215-1221. doi: 10.1515/BC.2000.149

van der Hoorn, R. A. L. (2008). Plant proteases: from phenotypes to molecular mechanisms. Annu. Rev. Plant Biol. 59, 191-223. doi: 10.1146/annurev.arplant. 59.032607 .092835

Verbruggen, N., and Hermans, C. (2008). Proline accumulation in plants: a review. Amino Acids 35, 753-759. doi: 10.1007/s00726-008-0061-6

Verdoy, D., Coba De La Peña, T., Redondo, F. J., Lucas, M. M., and Pueyo, J. J. (2006). Transgenic Medicago truncatula plants that accumulate proline display nitrogen-fixing activity with enhanced tolerance to osmotic stress. Plant Cell Environ. 29, 1913-1923. doi: 10.1111/j.1365-3040.2006.01567.x

Verslues, P. E., and Bray, E. A. (2006). Role of abscisic acid (ABA) and Arabidopsis thaliana $\mathrm{ABA}$-insensitive loci in low water potential-induced $\mathrm{ABA}$ and proline accumulation. J. Exp. Bot. 57, 201-212. doi: 10.1093/jxb/erj026

Walter, J., Nagy, L., Hein, R., Rascher, U., Beierkuhnlein, C., Willner, E., et al. (2011). Do plant remember drought? Hints towards a drought-memory in grasses. Environ. Exp. Bot. 71, 34-40. doi: 10.1016/j.envexpbot.2010.10.020

Wilkinson, S., Kudoyarova, G. R., Veselov, D. S., Arkhipova, T. N., and Davies, W. J. (2012). Plant hormone interactions: innovative targets for crop breeding and management. J. Exp. Bot. 63, 3499-3509. doi: 10.1093/jxb/ers148

Wu, G., Shao, H. B., Chu, L. Y., and Cai, J. W. (2007). Insights into molecular mechanisms of mutual effect between plants and the environment. A review. Agron. Sustain. Dev. 27, 69-78. doi: 10.1051/agro:2006031

Xavier-Filho, J., and Campos, F. A. P. (1989). "Proteinase inhibitors," in Toxicants of Plant Origin, Vol. 3, ed. P. R. Cheeke (Boca Raton, FL: CRC Press), 1-27.

Xiong, L., and Zhu, J. K. (2003). Regulation of abscisic acid biosynthesis. Plant Physiol. 133, 29-36. doi: 10.1104/pp.103.025395

Yamaguchi, M., Valliyodan, B., Zhang, J., Lenoble, M. E., Yu, O., Rogers, E. E., et al. (2010). Regulation of growth response to water stress in the soybean primary root. I. Proteomic analysis reveals region-specific regulation of phenylpropanoid metabolism and control of free iron in the elongation zone. Plant Cell Environ. 33, 223-243. doi: 10.1111/j.1365-3040.2009.02073.x

Yeu, S. Y., Park, B. S., Sang, W. G., Choi, Y. D., Kim, M. C., Song, J. T., et al. (2007). The serine proteinase inhibitor OsSerpin is a potent tillering regulator in rice. J. Plant Biol. 50, 600-604. doi: 10.1007/BF03030715

Zhang, L., Alfano, J. R., and Becker, D. F. (2015). Proline metabolism increases katG expression and oxidative stress resistance in Escherichia coli. J. Bacteriol. 197, 431-440. doi: 10.1128/JB.02282- 14

Zhang, L., and Becker, D. F. (2015). Connecting proline metabolism and signaling pathways in plant senescence. Front. Plant Sci. 6:552. doi: 10.3389/fpls.2015. 00552

Zhang, X., Liu, S., and Takano, T. (2008). Two cysteine proteinase inhibitors from Arabidopsis thaliana, AtCYSa and AtCYSb, increasing the salt, drought, oxidation and cold tolerance. Plant Mol. Biol. 68, 131-143. doi: 10.1007/s11103$008-9357-\mathrm{x}$ 
Zhu, J. K. (2002). Salt and drought stress signal transduction in plants. Annu. Rev. Plant Biol. 53, 247-273. doi: 10.1146/annurev.arplant.53.091401. 143329

Conflict of Interest Statement: The authors declare that the research was conducted in the absence of any commercial or financial relationships that could be construed as a potential conflict of interest.
Copyright $\odot 2017$ Islam, Leung, Nikmatullah, Dijkwel and McManus. This is an open-access article distributed under the terms of the Creative Commons Attribution License (CC BY). The use, distribution or reproduction in other forums is permitted, provided the original author(s) or licensor are credited and that the original publication in this journal is cited, in accordance with accepted academic practice. No use, distribution or reproduction is permitted which does not comply with these terms. 